\title{
Extranodal follicular dendritic cell sarcoma: A clinicopathological report of four cases and a literature review
}

\author{
RUI-FEN WANG ${ }^{1}$, WEI HAN ${ }^{2}$, LEI QI ${ }^{2}$, LI-HUI SHAN ${ }^{2}$, ZHENG-CAI WANG $^{3}$ and LI-FENG WANG ${ }^{1}$ \\ ${ }^{1}$ Department of Pathology, Xin Hua Hospital Affiliated to Shanghai Jiaotong University School of Medicine, Shanghai 200092; \\ ${ }^{2}$ Department of Pathology, The First Hospital of Harbin Medical University; \\ ${ }^{3}$ Department of Pathology, The Fourth Hospital of Harbin Medical University, Harbin 150001, P.R. China
}

Received February 9, 2014; Accepted October 20, 2014

DOI: $10.3892 / \mathrm{ol} .2014 .2681$

\begin{abstract}
The aim of the present study was to characterize the clinicopathological features of follicular dendritic cell sarcoma (FDCS), and to report the experience of the Xin Hua Hospital Affiliated to Shanghai Jiaotong University School of Medicine (Shanghai, China) with this entity. The clinicopathological findings of four cases that had recently been encountered and 142 previously reported cases in the English literature were evaluated. The current tumors were found in two male and two female patients, aged 49-76 years old, who exhibited a mean tumor size of $8.7 \mathrm{~cm}$. Three of the four cases were misdiagnosed during the initial diagnosis and one experienced intra-abdominal recurrence six months after the first diagnosis. Assessment of all 142 cases in the literature revealed a mild female predominance. The tumors exhibited a mean tumor size of $\sim 7.0 \mathrm{~cm}$. Histologically, the tumors were composed of plump spindle- or oval-shaped cells that exhibited eosinophilic cytoplasm and were arranged in sheets, storiform patterns or whorls. Immunohistochemically, the neoplastic cells expressed at least one of the FDC markers. Among the 130 cases with follow-up data, the overall recurrence, metastasis and mortality rates were $49.2 \%$ (64 cases), $21.5 \%$ (28 cases), and $13.8 \%$ (18 cases), respectively. FDCS can appear deceptively similar to other soft-tissue tumors, even poorly-differentiated carcinomas. A correct diagnosis requires a high degree of suspicion and immunohistochemical evaluation.
\end{abstract}

\section{Introduction}

Follicular dendritic cells (FDCs), which exhibit a dendritic configuration and occasional multinucleation, can be found

Correspondence to: Professor Li-Feng Wang, Department of Pathology, Xin Hua Hospital Affiliated to Shanghai Jiaotong University School of Medicine, 1665 KongJiang Road, Shanghai 200092, P.R. China

E-mail:wlf6009@163.com

Key words: follicular dendritic cell sarcoma, extranodal, literature review in primary and secondary lymphoid follicles at nodal or extranodal sites. FDCs are characterized by indistinct borders, oval nuclei, delicate nuclear membranes, faintly eosinophilic cytoplasm, small but distinct nucleoli, and their reaction to cluster of differentiation (CD)21, CD23, CD 35, fascin and clusterin (1). The cells play a major role in antigen presentation and antigen-dependent maturation of the B-cell immune response (2). Based on the normal distribution of FDCs, FDC sarcoma (FDCS) presents within the lymph nodes and at extranodal sites. Since FDCS has been fairly well-characterized morphologically and possesses a distinct immunophenotype, the possibility of diagnosis is currently more readily established for spindle cell lesions in the lymph nodes. However, extranodal FDCS is less well recognized, although its occurrence has been noted since 1994 (3). In the present study, the literature was reviewed in order to obtain a deeper recognition of FDCS arising from extranodal sites. Prior to 2013, there were only 142 cases of extranodal FDCS reported in the English language literature, with up to one-fourth of those cases being initially misdiagnosed. In the current study, four cases of extranodal FDCS are presented, and the clinicopathological features of extranodal FDCS reported in the literature are reviewed.

\section{Materials and methods}

Samples. The four cases were retrieved following consultation at the Xin Hua Hospital Affiliated to Shanghai Jiaotong University School of Medicine (Shanghai, China). One case has already been reported as FDCS (4), but additional tests have since been performed. The clinical information was obtained from the hospital and outpatient records, and from the contributing pathologists and clinicians. Histological materials were processed in a routine manner, with formalin fixation and paraffin embedding for hematoxylin and eosin staining. Ethical approval for this study was obtained from the Ethics Committee of Xin Hua Hospital Affiliated to Shanghai Jiaotong University School of Medicine.

Immunohistochemistry. Immunohistochemical staining was performed on the formalin-fixed, paraffin-embedded tissue sections using the EnVision method (Leica BOND-MAX, Leica Biosystems, Newcastle Upon Tyne, UK). The antibodies 
used in the immunohistochemistry were for CD21, CD23, CD35, vimentin, CD20, CD3, desmin, CD68, cytokeratin (CK), CD117, CD34, thyroid transcription factor-1, S100 protein, human melanoma black 45 (HMB45), smooth muscle actin (SMA), epithelial membrane antigen (EMA) and Ki-67. Appropriate positive and negative controls were simultaneously evaluated.

Literature review. Previous studies were obtained from the MEDLINE database, a major index literature source, using the term 'follicular dendritic cell sarcoma/tumor'. Nodal FDCS was not included. An effort was made to identify cases that had been reported more than once and only the case with the most recently updated information was included in the present report. A total of 142 cases of extranodal FDCS were retrieved from the English literature (5-86). A total of 11 cases were excluded from the analysis due to omitted clinical data.

Statistical analysis. The association between the various clinicopathological features and a higher event rate (recurrence, metastases, and mortality) were assessed using the $\chi^{2}$ test. Data analyses were generated using SPSS for Windows, version 13.0 (SPSS, Inc., Chicago, IL, USA). P $<0.05$ was used to indicate a statistically significant difference.

\section{Results}

\section{Report of four cases}

Clinical data. The case summaries of the present four cases of extranodal FDCS are shown in Table I. The tumors were located in the tonsils, stomach, liver and lungs, respectively.

Histopathological findings. Macroscopically, the four tumors were well-circumscribed, exhibiting a solid, nodular, grey-yellow or dust-colored cut surface, similar to sarcoma or lymphoma. Microscopically, the tumors were relatively well-circumscribed (Fig. 1). Cases one and four revealed an epithelioid cell morphology, with a whorled, diffuse or trabecular growth pattern, while cases two and three exhibited an increased proportion of spindled cells. The growth pattern in these cases was fascicular, storiform and whorled (Fig. 2). In all cases, the tumor cells possessed a moderate amount of faintly eosinophilic cytoplasm and indistinct cell borders. Binucleated or multinucleated tumor cells were occasionally observed. The nuclei were oval to elongated in shape, with thin and lightly-stained purplish nuclear membranes, vesicular or stippled chromatin and distinct nucleoli. Certain nuclei contained round intranuclear pseudoinclusions (Fig. 2). Mitoses were not prominent and were absent in three cases and in 6-8/10 high-power fields (HPFs) in case two. Necrosis was observed in three cases. There were small lymphocytes scattered throughout the tumors and clustered around vessels. In case two, certain irregular pseudolacuna-like blood vessels were found, the insides of which exhibited plump eosinophilic protein-like liquids that resembled the perivascular spaces observed in thymoma.

Immunohistochemical findings. The staining of CD21, CD23, CD35 and vimentin was performed for all four cases, while the staining of CD68, S-100 and EMA was performed for only three cases. Immunohistochemically, all four cases were diffusely positive for CD21, CD23 and vimentin expression, and focally positive for CD35 expression. Two of three

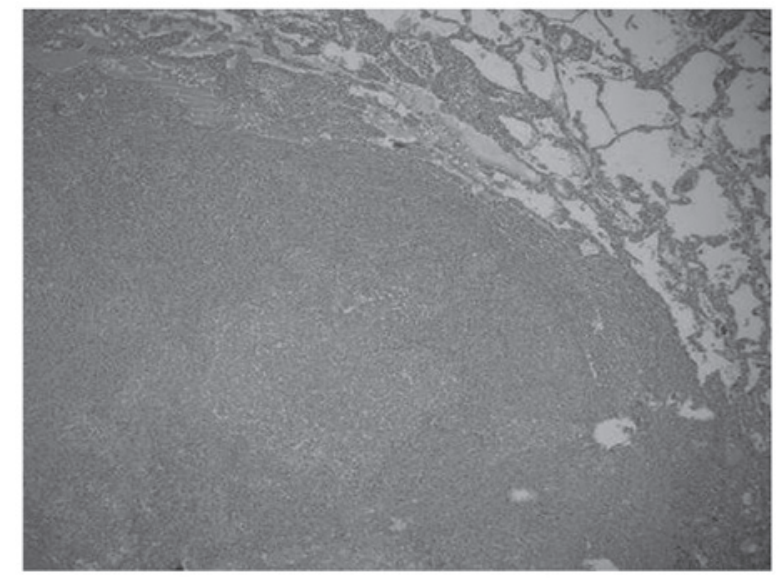

Figure 1. Case four: Follicular dendritic cell sarcoma in the lung exhibiting sharp demarcation from the residual parenchyma.

cases were focally positive for CD68 expression, and one of three cases was focally positive for S-100 and EMA expression (Fig. 3). Case two exhibited a negative result for the expression of GIST markers CD34 and CD117, while case four exhibited a negative result for thyroid transcription factor and the melanoma marker HMB45. Staining for these markers was not performed in the other cases. All the present cases were negative for CK and SMA. For the associated lymphocytes, T cells $\left(\mathrm{CD}^{+}\right)$outnumbered $\mathrm{B}$ cells $\left(\mathrm{CD} 20^{+}\right)$. The $\mathrm{Ki}-67$ labeling index of case one was $>1 \%$, while the indexes of cases two and four were 15 and $40 \%$, respectively.

\section{Literature review}

Clinical features. A total of 142 cases of extranodal FDCS were retrieved from the literature. The patients, 77 females and 65 males (female to male ratio, 1.2:1), ranged in age from 9-82 years old. The tumor affected various anatomical sites. The more predominant extranodal sites of tumor involvement were the tonsils (28), pharynx (19), liver (18), spleen (17), intra-abdominal but external viscera (14), soft tissue of the neck (11), mediastinum (6), lungs (4), gastrointestinal tract (three in the stomach, four in the small bowel, two in the large intestine and one in the anal canal), thyroid, breast, palate, parotid gland (3) and pancreas (2). Other organ sites consisted of the intracalvarium, pleura, dura mate spinalis, pelvis and soft tissue of the thigh, with one case occurring in each location. In total, 12 cases exhibited lymph node and extranodal FDCS, and 9 cases exhibited distant metastases at the time of presentation.

Pathological findings. The average size of the tumors in all sites was $7.0 \mathrm{~cm}$, with a range of $1-22 \mathrm{~cm}$. Intra-abdominal tumors $(\mathrm{n}=55)$ exhibited an average tumor size of $10.2 \mathrm{~cm}$ (range, $3-22 \mathrm{~cm}$ ), whereas the average tumor size of extra-abdominal sites ( $\mathrm{n}=72$ ) was only $5.4 \mathrm{~cm}$ (range, $1-16 \mathrm{~cm}$ ) $(\mathrm{P}<0.05)$. Data regarding tumor size were unavailable for 15 cases.

The macroscopic and microscopic findings of the cases from the literature were similar to those described in the present four cases. Macroscopically, the tumors were well-circumscribed with a solid, nodular, grey-yellow or dust-colored cut surface, similar to sarcoma or lymphoma. Microscopically, the tumors were circumscribed from the surrounding parenchyma, with or without a fibrous capsule. The tumor cells varied from 
Table I. Clinical data of four novel cases of extranodal follicular dendritic cell sarcoma.

\begin{tabular}{|c|c|c|c|c|c|c|c|c|}
\hline Case & Gender & Age & Site & $\begin{array}{l}\text { Maximal } \\
\text { size, } \mathrm{cm}\end{array}$ & Manifestation & Initial diagnosis & Treatment & $\begin{array}{c}\text { Outcome at } \\
\text { follow-up (months) }\end{array}$ \\
\hline 1 & M & 65 & Tonsil & No data & Tonsil pain & $\mathrm{SCC}$ & Tonsillectomy & NED (25) \\
\hline 2 & $\mathrm{~F}$ & 53 & Stomach & 14 & $\begin{array}{l}\text { Debilitation, } \\
\text { abdominal } \\
\text { distention, } \\
\text { anepithymia }\end{array}$ & GIST & $\begin{array}{l}\text { Surgery } \\
\text { Radiotherapy } \\
\text { Hemotherapy }\end{array}$ & AWD (10) \\
\hline 3 & M & 49 & Liver & 9 & $\begin{array}{l}\text { Right upper } \\
\text { quadrant pain }\end{array}$ & $\begin{array}{l}\text { Inflammatory } \\
\text { pseudotumor }\end{array}$ & Surgery & $\begin{array}{l}\text { Intra-abdominal } \\
\text { recurrence }(8)\end{array}$ \\
\hline 4 & $\mathrm{~F}$ & 76 & Lung & 3 & Dyspnea & $\begin{array}{l}\text { Malignant } \\
\text { melanoma }\end{array}$ & Surgery & $\begin{array}{l}\text { Succumbed to } \\
\text { disease }\end{array}$ \\
\hline
\end{tabular}

NED, no evidence of disease; AWD, alive with disease; SCC, squamous cell carcinoma; GIST, gastrointestinal stromal tumor.

Table II. Analysis of factors associated with a higher risk of recurrence or mortality in localized disease.

\begin{tabular}{|c|c|c|c|c|c|}
\hline Parameter & Disease-free, $\mathrm{n}$ & Recurrence, $\mathrm{n}$ & Mortality, n & P-value ${ }^{a}$ & $\mathrm{P}$-value ${ }^{\mathrm{b}}$ \\
\hline Age, years & & & & 0.017 & 0.752 \\
\hline$\geq 50$ & 38 & 10 & 7 & & \\
\hline$<50$ & 25 & 21 & 8 & & \\
\hline Gender & & & & 0.310 & 0.765 \\
\hline Female & 34 & 20 & 8 & & \\
\hline Male & 29 & 11 & 7 & & \\
\hline Tumor size, $\mathrm{cm}$ & & & & 0.391 & 0.006 \\
\hline$\geq 7.5$ & 18 & 7 & 9 & & \\
\hline$<7.5$ & 41 & 18 & 4 & & \\
\hline Location & & & & 0.128 & 0.095 \\
\hline Intra-abdominal & 28 & 7 & 9 & & \\
\hline Extra-abdominal & 36 & 23 & 6 & & \\
\hline Mitotic count & & & & 0.304 & 0.004 \\
\hline$\geq 5 / 10 \mathrm{HPFs}$ & 7 & 8 & 6 & & \\
\hline$<5 / 10$ HPFs & 31 & 11 & 1 & & \\
\hline Necrosis & & & & 0.012 & 0.367 \\
\hline Present & 24 & 5 & 4 & & \\
\hline Absent & 14 & 12 & 1 & & \\
\hline
\end{tabular}

${ }^{a}$ Factors associated with recurrence; ${ }^{b}$ factors associated with mortality. HPFs, high-power fields.

plump and spindled to epithelioid, with a moderate amount of faintly eosinophilic cytoplasm and indistinct cell borders. Binucleated or multinucleated tumor cells were occasionally observed. The nuclei were oval to elongated in shape, with a thin and lightly stained purplish nuclear membrane, vesicular or stippled chromatin, and distinct nucleoli. Intranuclear pseudoinclusions were found in certain cases. A mitotic count was available in 80 cases, with a median of 4/10 HPFs ranging between 0 and 50/10 HPFs. In total, 51 cases possessed a mitotic count of $<5 / 10 \mathrm{HPFs}$. Information on necrosis was available in 70 cases, of which 34 cases (48.6\%) exhibited coagulative necrosis. There were small lymphocytes scattered throughout the tumors and clustered around vessels.

Immunohistochemically, all the cases were positive for at least one of the FDC markers, including CD21, CD23, CD35, fascin and clusterin, and were negative for CK. Staining for CD117, CD34, desmin, HMB45 and CD1 $\alpha$, CD68, S100, and EMA revealed variable results among the different cases. Desmoplakin, a desmosome-associated protein, was detected in the majority of the cases. The associated lymphocytes were 

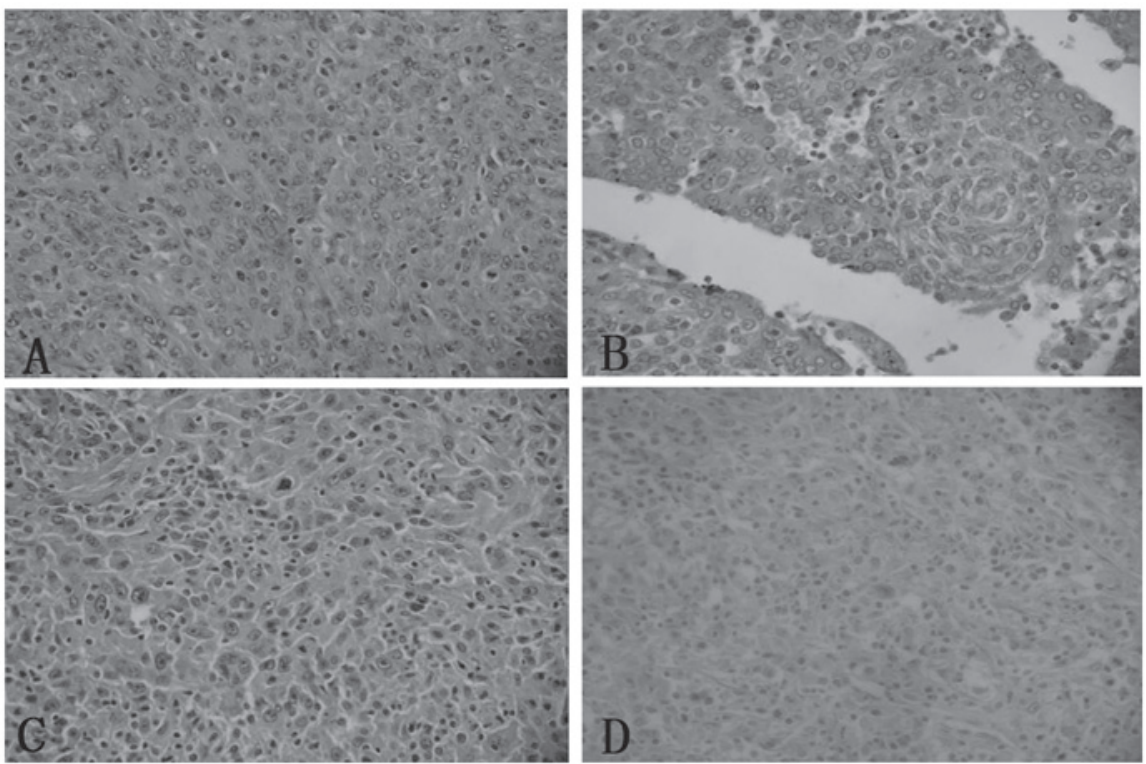

Figure 2. Growth patterns of follicular dendritic cell sarcoma demonstrating the characteristic sprinkling of small lymphocytes throughout the tumor. (A) Case two: Interlacing fascicles of spindled cells with oval nuclei, empty nucleoplasm and distinct small nucleoli. (B) Case one: Whorled pattern mimicking a feature of meningioma. (C) Case four: Diffuse growth pattern with multinucleated tumor cells. (D) Case three: Storiform pattern with intranuclear pseudoinclusion.
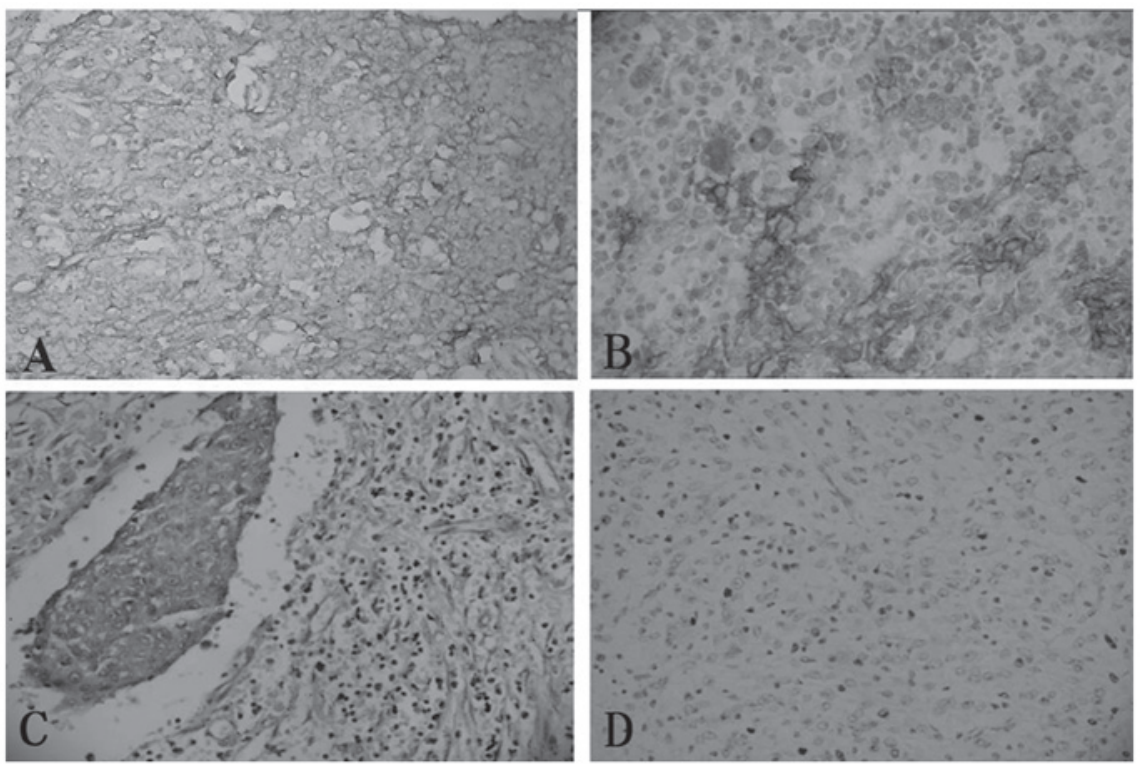

Figure 3. Immunohistochemical staining. (A) Case one: Positive staining for cluster of differentiation (CD)21. (B) Case four: Positive staining for CD23 demonstrating a trabecular growth pattern. (C) Case one: Focal staining for EMA. (D) Case two: A Ki-67 index of $15 \%$.

more commonly $\mathrm{T}$ cells $\left(\mathrm{CD}^{+}\right)$rather than $\mathrm{B}$ cells $\left(\mathrm{CD} 20^{+}\right)$. Prominent cell processes that were focally joined by well-formed cell junctions and desmosome-like cytoplasm were exhibited ultrastructurally by the tumor cells.

Discordant diagnoses at the initial evaluation. Overall, 40 cases were misdiagnosed at the time of the initial evaluation. In each of these cases, the diagnosis of FDCS was not considered at the initial evaluation. The disease entities that were considered consisted of interdigitating reticulum cell sarcoma, minor salivary gland tumors, malignant peripheral nerve sheath tumors, reactive response, inflammatory pseudotumors, malignant fibrous histocytomas, meningioma, mesenchymal tumors with neural differentiation, schwannoma, Hodgkin's lymphoma, angiosarcoma, malignant melanoma, large-cell lymphoma, spindle cell carcinoma, primitive neuroectodermal tumors, malignant myoepithelial carcinoma and gastrointestinal stromal tumors.

Correlation between clinicopathological findings and patient outcome. Follow-up information was available in 130 cases, with a follow-up duration period of 0.5 to 324 months (mean, 34.5 months). The overall recurrence, metastasis and mortality rates were $49.2 \%$ (64 cases), $21.5 \%$ (28 cases), and $13.8 \%$ (18 cases), respectively. Local recurrence occurred in 25 patients $(20.5 \%)$ following resection (range, 6-180 months). Distant metastases occurred in 28 patients and the metastatic sites included the liver, lung, bones, ovaries, thyroid gland, omentum, lymph nodes and soft tissue. At follow-up, it was determined that 18 (13.8\%) patients had succumbed to the disease, 38 (29.2\%) were alive with the disease, and 74 (56.9\%) patients were alive with no 
evidence of the disease. Both clinicopathological features and follow-up information were available for 109 patients; the association between the various clinicopathological features of early-stage disease and a higher event rate (recurrence and mortality) was analyzed for these patients, the results of which are summarized in Table II. A large tumor size $(\geq 7.5 \mathrm{~cm})$ and high mitotic rate ( $\geq 5 / 10 \mathrm{HPF}$ ) were associated with mortality, but not recurrence.

\section{Discussion}

The majority of FDCS occurs in adults, with a mild female predilection. The clinical characteristics of FDCS include a painless mass. It is important that doctors are aware of FDCS and are able to recognize this tumor, as it is extremely similar to a wide range of other tumors and tumor-like lesions. Usually, FDCS is not considered in routine diagnoses, particularly when it occurs in extranodal sites. FDCS can be missed even after immunohistochemical studies, as the markers for FDC are not included among the routine antibody panel that is used for the investigation of poorly-differentiated neoplasms. Thus, tumors arising from extranodal sites are often misdiagnosed or excluded during the initial diagnosis, and this is corrected only when there is tumor recurrence or metastasis (78). In the present four cases, three were misdiagnosed, which could lead to unnecessary treatment and associated morbidity. This prompted the investigation of potential diagnostic pitfalls and a detailed analysis of extranodal FDCS.

The diagnosis of FDCS is established based on morphological and immunohistochemical findings. Histologically, the tumors in the present study were composed of spindle to oval-shaped cells, which were arranged in sheets, interlacing fascicles or whorls. The tumor cells exhibited plump eosinophilic cytoplasm, with ill-defined cell borders, forming a less diffuse growth pattern. The nuclei of the tumor cells were small, oval or round in shape, and exhibited a vesicular chromatin pattern. Certain multinucleate tumor cells were also present. Nuclear pleomorphisms and scattered mitotic figures, often $<3$ mitoses/10 HPFs, were observed. The neoplastic cells were intermixed with small mature lymphocytes and plasma cells, which surrounded the blood vessel and formed a cuff-like structure.

The correct diagnosis of FDCS must also be made from immunohistochemistry studies. Ultrastructural studies are desirable when making a diagnosis of FDCS, but are not essential. FDCS cells demonstrate a similar immunophenotype to normal FDCs. CD21, CD23, CD35, fascin, and clusterin are more specific markers for FDCS. CD68, S-100, EMA, and LCA are variably immunoreactive, while results for CK, CD1 $\alpha$, CD31, CD34, and HMB-45 are negative (84). A previous study demonstrated that EGFR and clusterin exhibit high specificity for diagnosis (1). Fascin has been revealed to be extremely non-specific among spindle cell tumors, indicating that they do not have a follicular dendritic lineage (1). High D2-40 expression has been revealed in FDCS, while weak or no expression has been found in other dendritic cell tumors $(41,87)$. Electron microscopy reveals that the tumor cells have long, slender cytoplasmic processes, which were connected by desmosomes, few cellular organs and no Birbeck granules (78).
Although FDCS possesses certain morphological and immunophenotypical features, those that occur in extranodal sites are particularly rare and extremely similar to other soft-tissue tumors, even poorly-differentiated cancers. For example, in the cases from the literature review, FDCS of the parapharyngeal region was misdiagnosed as ectopic meningioma (24), pars palatalis was misdiagnosed as acinic cell carcinoma (88) and primary FDCS of the alimentary tract was misdiagnosed as mesenchymal neoplasm of the abdominal cavity (43), diffuse large-cell lymphoma of the liver (8) and low-degree malignant tumor of the mesentery (57).

Therefore, an awareness of the morphological features of FDCS and the appropriate application of FDC markers for any tumors exhibiting an unusual appearance, should aid a correct diagnosis (74). In case two of the present study, stomach FDCS was misdiagnosed as a GIST, in which the tumor cells usually exhibit less eosinophilic cytoplasm compared with the cells of spindle cell tumors, which exhibit greater specific differentiation, similar to smooth muscle and neurogenic tumors. Immunohistochemically, the tumor cells of GISTs are positive for CD117 and CD34, but negative for FDC markers. Another type of neoplasm that has a dendritic cell origin is interdigitating dendritic cell sarcoma, which also shares certain immunophenotypical, histological and ultrastructural features with FDCS. However, interdigitating dendritic cell sarcoma is S-100-positive, but negative for FDC markers. When FDC markers are present and there is no CD45 expression, the diagnosis of interdigitating dendritic cell sarcoma can be excluded. Sparse intracytoplasmic organelles and interdigitating cytoplasmic processes are typical ultrastructural features, but interdigitating dendritic cell sarcoma does not exhibit desmosomes. In addition, a differential diagnosis should include malignant melanoma, ectopic meningioma, malignant fibrohistiocytoma, ectopic thymoma, malignant peripheral nerve sheath tumor, lymphepithelioma and malignant lymphoma. Among these possibilities, malignant melanoma is positive for HMB-45 and ectopic meningioma is positive for vimentin and EMA. Malignant fibrohistiocytoma is characterized by spindle cells in a storiform pattern, multinucleate tumor giant cells, marked cytological atypia and positive histiocyte marker expression. Ectopic thymoma is positive for CK and terminal deoxynucleotidyl transferase expression in lymphocytes. However, all the aforementioned lesions are negative for FDC markers (77).

The etiopathogenesis of FDCS remains unclear. Novel investigations have revealed that FDCS was associated with hyaline-vascular Castleman's disease, in which FDC hyperplasia can develop into FDCS, similar to certain nodal counterparts (20). Cheuk et al (45) reported a series of inflammatory pseudotumor (IPT)-like FDCS, which were positive for Epstein-Barr virus-encoded RNA (EBER) in all cases. Shia et al (14) suggested that the IPT-like FDCS may represent an earlier stage of FDCS, which may exert an inciting factor associated with EBV. Upon review of studies of cases that had previously been tested for EBV, it was discovered that 10 out of 11 cases of hepatic FDCS exhibited positive EBER expression by in situ hybridization (47), whereas 11 out of 17 splenic cases were positive for the virus. EBV was not detected in any of the cases located in other sites. Recently, it was found that tumor cells were uniformly 
positive for EBV in all six studied cases of IPT-like FDC sarcoma of the spleen, and there were predominant immunoglobulin $(\mathrm{Ig}) \mathrm{G}^{+}$plasma cells in the tumor nodules, suggesting that IPT-like FDC sarcoma of the spleen may be closely associated with EBV and the IgG4-associated disease (86). Therefore, there is a pathogenetic difference between liver and splenic FDCS and other FDCS. However, EBV was not detected in case three, an FDCS of the liver, in the present study. In addition, certain studies revealed that FDCS coexisting with myasthenia gravis was also associated with immature $T$ cells. These cases suggested that myasthenia gravis may be a paraneoplastic manifestation of FDCS and that FDCS may be capable of mediating aberrant immune activation (89-91). Other data suggested that the p53-mediated pathway may possibly be involved in the development or progression of FDCS (75). However, the association was not evident in any lesion in the present cases.

The biological behavior of FDCS is difficult to predict, as it is generally considered to be a low-grade soft-tissue sarcoma. Although originally known as an FDC tumor, the term FDCS was proposed by Chan et al (6) in order to emphasize the clinical behavior of the neoplasm as a sarcoma rather than a lymphoma. Until recently, the tumor was believed to be indolent with a tendency to recur, but with a low risk of metastasis. Studies of larger cohorts and for longer follow-up periods have since concluded that FDCS is more aggressive than previously hypothesized, and that the tumor should be considered as an intermediate-grade malignancy at least $(6,92,93)$. In the present study, a large tumor size and a high mitotic rate were found to be associated with mortality, but an intra-abdominal location and the presence of necrosis were not associated with a poor prognosis. However, other studies have found that poor prognostic factors included an intra-abdominal location, a tumor size of $>6 \mathrm{~cm}$, a high mitotic rate, necrosis and nuclear pleomorphism $(92,93,14)$. In case two of the present study, cell atypia and 6-8 mitoses/10 HPFs were observed, which indicated a poor prognosis. There were multiple metastases in the liver at the time of surgery. In addition, the marked intratumoral immature T-cell burden may also perform a role as an adverse prognostic factor in FDCS (89). Radical resection of the tumor is the primary therapy, but the value of radiotherapy and chemotherapy in the treatment of this neoplasm remains uncertain.

In conclusion, extranodal FDCS is a rare, often misdiagnosed, malignant tumor. An increased awareness of the morphological spectrum of FDCS and appropriate immunostains for FDC differentiation should aid in the recognition of FDCS. It is imperative for the biological behavior of this tumor to be clearly recognized. Increased awareness of the existence of FDCS may aid a reduction in the potential for diagnostic error.

\section{References}

1. Grogg KL, Macon WR, Kurtin PJ and Nascimento AG: A survey of clusterin and fascin expression in sarcomas and spindle cell neoplasms: strong clusterin immunostaining is highly specific for follicular dendritic cell tumor. Mod Pathol 18: 260-266, 2005

2. Wu J, Qin D, Burton GF, Szakal AK and Tew JG: Follicular dendritic cell-derived antigen and accessory activity in initiation of memory IgG responses in vitro. J Immunol 157: 3404-3411, 1996.
3. Chan JK, Tsang WY and Ng CS: Follicular dendritic cell tumor and vascular neoplasm complicating hyaline-vascular Castleman's disease. Am J Surg Pathol 18: 517-525, 1994.

4. Wang LF, Wang RF, Wang ZC, et al: Follicular dendritic cell sarcoma of stomach: report of a case. Zhonghua Bing Li Xue Za Zhi 37: 210-211, 2008 (In Chinese).

5. Perez-Ordonez B, Erlandson RA and Rosai J: Follicular dendritic cell tumor: report of 13 additional cases of a distinctive entity. Am J Surg Pathol 20: 944-955, 1996.

6. Chan JK, Fletcher CD, Nayler SJ and Cooper K: Follicular dendritic cell sarcoma. Clinicopathologic analysis of 17 cases suggesting a malignant potential higher than currently recognized. Cancer 79: 294-313, 1997.

7. Biddle DA, Ro JY, Yoon GS, et al: Extranodal follicular dendritic cell sarcoma of the head and neck region: three new cases, with a review of the literature. Mod Pathol 15: 50-58, 2002.

8. Vargas H, Mouzakes J, Purdy SS, Cohn AS and Parnes SM: Follicular dendritic cell tumor: an aggressive head and neck tumor. Am J Otolaryngol 23: 93-98, 2002.

9. Satoh K, Hibi G, Yamamoto Y, et al: Follicular dendritic cell tumor in the oro-pharyngeal region: report of a case and a review of the literature. Oral Oncol 39: 415-419, 2003.

10. Tisch M, Hengstermann F, Kraft K, von Hinüber G and Maier H: Follicular dendritic cell sarcoma of the tonsil: report of a rare case. Ear Nose Throat J 82: 507-509, 2003.

11. Grogg KL, Lae ME, Kurtin PJ and Macon WR: Clusterin expression distinguishes follicular dendritic cell tumors from other dendritic cell neoplasms: report of a novel follicular dendritic cell marker and clinicopathologic data on 12 additional follicular dendritic cell tumors and 6 additional interdigitating dendritic cell tumors. Am J Surg Pathol 28: 988-998, 2004.

12. Idrees MT, Brandwein-Gensler M, Strauchen JA, Gil J and Wang BY: Extranodal follicular dendritic cell tumor of the tonsil: report of a diagnostic pitfall and literature review. Arch Otolaryngol Head Neck Surg 130: 1109-1113, 2004.

13. Domínguez-Malagón H, Cano-Valdez AM, Mosqueda-Taylor A and Hes O: Follicular dendritic cell sarcoma of the pharyngeal region: histologic, cytologic, immunohistochemical, and ultrastructural study of three cases. Ann Diagn Pathol 8: 325-332, 2004.

14. Shia J, Chen W, Tang LH, et al: Extranodal follicular dendritic cell sarcoma: clinical, pathologic, and histogenetic characteristics of an underrecognized disease entity. Virchows Arch 449: 148-158, 2006.

15. Aydin E, Ozluoglu LN, Demirhan B and Arikan U: Follicular dendritic cell sarcoma of the tonsil: case report. Eur Arch Otorhinolaryngol 263: 1155-1157, 2006.

16. Clement P, Saint-Blancard P, Minvielle F, Le Page P and Kossowski M: Follicular dendritic cell sarcoma of the tonsil: a case report. Am J Otolaryngol 27: 207-210, 2006.

17. McDuffie C, Lian TS and Thibodeaux J: Follicular dendritic cell sarcoma of the tonsil: a case report and literature review. Ear Nose Throat J 86: 234-235, 2007.

18. Fan YS, Ng WK, Chan A, et al: Fine needle aspiration cytology in follicular dendritic cell sarcoma: a report of two cases. Acta Cytol 51: 642-647, 2007.

19. Vaideeswar P, George SM, Kane SV, Chaturvedi RA and Pandit SP: Extranodal follicular dendritic cell sarcoma of the tonsil - case report of an epithelioid cell variant with osteoclastic giant cells. Pathol Res Pract 205: 149-153, 2009.

20. Chan AC, Chan KW, Chan JK, et al: Development of follicular dendritic cell sarcoma in hyaline-vascular Castleman's disease of the nasopharynx: tracing its evolution by sequential biopsies. Histopathology 38: 510-518, 2001.

21. Georgalas C, Kanagalingam J, Gallimore A and O'Flynn P: Follicular dendritic cell sarcoma arising from the hypopharynx. J Laryngol Otol 118: 317-318, 2004.

22. Encabo RS, McHugh J, Carrau RL, Kassam A and Heron D: Follicular dendritic cell sarcoma of the nasopharynx. Am J Otolaryngol 29: 262-264, 2008.

23. Araújo VC, Martins MT, Salmen FS and Araújo NS: Extranodal follicular dendritic cell sarcoma of the palate. Oral Surg Oral Med Oral Pathol Oral Radiol Endod 87: 209-214, 1999.

24. Desai S, Deshpande RB and Jambhekar N: Follicular dendritic cell tumor of the parapharyngeal region. Head Neck 21: 164-167, 1999.

25. Galati LT, Barnes EL and Myers EN: Dendritic cell sarcoma of the thyroid. Head Neck 21: 273-275, 1999.

26. Chou YY, How SW and Huang CH: Follicular dendritic cell sarcoma of the soft palate. J Formos Med Assoc 104: 843-847, 2005. 
27. Yu L and Yang SJ: Primary follicular dendritic cell sarcoma of the thyroid gland coexisting with Hashimoto's thyroiditis. Int J Surg Pathol 19: 502-505, 2011.

28. Fisher C, Magnusson B, Hardarson S and Smith ME: Myxoid variant of follicular dendritic cell sarcoma arising in the breast. Ann Diagn Pathol 3: 92-98, 1999.

29. Choi PC, To KF, Lai FM, et al: Follicular dendritic cell sarcoma of the neck: report of two cases complicated by pulmonary metastases. Cancer 89: 664-672, 2000.

30. Pruneri G, Masullo M, Renne G, et al: Follicular dendritic cell sarcoma of the breast. Virchows Arch 441: 194-199, 2002.

31. Bradshaw EJ, Wood KM, Hodgkinson P, Lucraft H and Windebank KP: Follicular dendritic cell tumour in a 9-year-old child. Pediatr Blood Cancer 45: 725-727, 2005.

32. Kapucuoglu N, Percinel S, Ventura T, et al: Dendritic cell sarcomas/tumours of the breast: report of two cases. Virchows Arch 454: 333-339, 2009.

33. Fassina A, Marino F, Poletti A, et al: Follicular dendritic cell tumor of the mediastinum. Ann Diagn Pathol 5: 361-367, 2001.

34. Kröber SM, Marx A, Aebert H, Dohmen BM and Kaiserling E: Sarcoma of follicular dendritic cells in the dorsal mediastinum. Hum Pathol 35: 259-263, 2004.

35. Kawasaki T, Watanabe G, Hasegawa G and Naito M: Multiple extranodal follicular dendritic cell tumors initially presenting in the soft tissue in the chest wall. Pathol Int 56: 30-34, 2006.

36. Guettier C, Validire P, Emilie D, et al: Follicular dendritic cell tumor of the mediastinum: expression of fractalkine and SDF-1alpha as mast cell chemoattractants. Virchows Arch 448 : 218-222, 2006

37. Jiang L, Admirand JH, Moran C, Ford RJ and Bueso-Ramos CE: Mediastinal follicular dendritic cell sarcoma involving bone marrow: a case report and review of the literature. Ann Diagn Pathol 10: 357-362, 2006.

38. Han JH, Kim SH, Noh SH, et al: Follicular dendritic cell sarcoma presenting as a submucosal tumor of the stomach. Arch Pathol Lab Med 124: 1693-1696, 2000

39. Shah RN, Ozden O, Yeldandi A, et al: Follicular dendritic cell tumor presenting in the lung: a case report. Hum Pathol 32: 745-749, 2001

40. Kovács RB, Sattar HA, Krausz T, et al: Primary follicular dendritic cell sarcoma of the lung. Histopathology 49: 431-433, 2006.

41. Denning KL, Olson PR, Maley RH Jr, et al: Primary pulmonary follicular dendritic cell neoplasm: a case report and review of the literature. Arch Pathol Lab Med 133: 643-647, 2009.

42. Fonseca R, Tefferi A and Strickler JG: Follicular dendritic cell sarcoma mimicking diffuse large cell lymphoma: a case report. Am J Hematol 55: 148-155, 1997.

43. Shek TW, Liu CL, Peh WC, Fan ST and Ng IO: Intra-abdominal follicular dendritic cell tumour: a rare tumour in need of recognition. Histopathology 33: 465-470, 1998.

44. Chang KC, Jin YT, Chen FF and Su IJ: Follicular dendritic cell sarcoma of the colon mimicking stromal tumour. Histopathology 38: 25-29, 2001.

45. Cheuk W, Chan JK, Shek TW, et al: Inflammatory pseudotumor-like follicular dendritic cell tumor: a distinctive low-grade malignant intra-abdominal neoplasm with consistent Epstein-Barr virus association. Am J Surg Pathol 25: 721-731, 2001.

46. Agaimy A and Wünsch PH: Follicular dendritic cell tumor of the gastrointestinal tract: Report of a rare neoplasm and literature review. Pathol Res Pract 202: 541-548, 2006

47. Torres U,Hawkins WG, Antonescu CR and DeMatteo RP: Hepatic follicular dendritic cell sarcoma without Epstein-Barr virus expression. Arch Pathol Lab Med 129: 1480-1483, 2005.

48. Khalid T and Folman R: Symptoms in cancer patients and an unusual tumor: case three. Follicular dendritic cell sarcoma. J Clin Oncol 23: 9425-9426, 2005.

49. Horiguchi H, Matsui-Horiguchi M, Sakata H, et al: Inflammatory pseudotumor-like follicular dendritic cell tumor of the spleen. Pathol Int 54: 124-131, 2004.

50. Ren R, Sun X, Staerkel G, Sneige N and Gong Y: Fine-needle aspiration cytology of a liver metastasis of follicular dendritic cell sarcoma. Diagn Cytopathol 32: 38-43, 2005.

51. Granados R, Aramburu JA, Rodríguez JM and Nieto MA Cytopathology of a primary follicular dendritic cell sarcoma of the liver of the inflammatory pseudotumor-like type. Diagn Cytopathol 36: 42-46, 2008.

52. Moriki T, Takahashi T, Wada M, et al: Follicular dendritic cell tumor of the mesentery. Pathol Res Pract 193: 629-639, discussion 640-642, 1997.

53. Yamakawa M, Andoh A, Masuda A, et al: Follicular dendritic cell sarcoma of the omentum. Virchows Arch 440: 660-663, 2002.
54. Sander B, Middel P, Gunawan B, et al: Follicular dendritic cell sarcoma of the spleen. Hum Pathol 38: 668-672, 2007.

55. Yakushijin Y, Shikata H, Kito K, et al: Follicular dendritic cell tumor as an unknown primary tumor. Int J Clin Oncol 12: 56-58, 2007.

56. Chiaramonte MF, Lee D, Abruzzo LV, Heyman M and Bass BL: Retroperitoneal follicular dendritic cell sarcoma presenting as secondary amyloidosis. Surgery 130: 109-111, 2001.

57. Wang J, Kong Y, Lu H and Xu Y: Two cases of extranodal follicular dendritic cell sarcoma. Chin Med J (Engl) 116: 794-797, 2003.

58. Marzano AV, Vezzoli P, Mariotti F, et al: Paraneoplastic pemphigus associated with follicular dendritic cell sarcoma and Castleman disease. Br J Dermatol 153: 214-215, 2005.

59. Androulaki A, Liapis G, Alexandrou P and Lazaris AC: Retroperitoneal follicular dendritic cell sarcoma. Int J Hematol 84: 2, 2006

60. Padilla-Rodríguez AL, Bembassat $M$, Lazaro $M$ and Ortiz-Hidalgo C: Intra-abdominal follicular dendritic cell sarcoma with marked pleomorphic features and aberrant expression of neuroendocrine markers: report of a case with immunohistochemical analysis. Appl Immunohistochem Mol Morphol 15: 346-352, 2007.

61. Loo CK, Henderson C and Rogan K: Intraabdominal follicular dendritic cell sarcoma: report of a case with fine needle aspiration findings. Acta Cytol 45: 999-1004, 2001

62. Hasselblatt M, Sepehrnia A, von FM and Paulus W: Intracranial follicular dendritic cell sarcoma. Case report. J Neurosurg 99: 1089-1090, 2003

63. Li CF, Chuang SS and Lin CN: A 70-year-old man with multiple intra-abdominal masses and liver and spleen metastases. Intra-abdominal follicular dendritic cell sarcoma with liver and spleen metastases. Arch Pathol Lab Med 129: e130-e131, 2005.

64. Shen SC, Wu CC, Ng KF, et al: Follicular dendritic cell sarcoma mimicking giant cell carcinoma of the pancreas. Pathol Int 56: 466-470, 2006

65. Choi JW, Lee JH, Kim A, et al: Follicular dendritic cell sarcoma arising in the dura mater of the spine. Arch Pathol Lab Med 130: 1718-1721, 2006

66. Karaman E, Saritzali G, Kilic E, Korkut N and Enver O Follicular dendritic cell sarcoma of the parotid gland recurring 6 times within 12 years. J Craniofac Surg 20: 2171-2172, 2009.

67. Yamada Y, Haga H, Hernandez M, et al: Follicular dendritic cell sarcoma of small intestine with aberrant T-cell marker expression. Pathol Int 59: 809-812, 2009.

68. Hartert M, Ströbel P, Dahm M, et al: A follicular dendritic cell sarcoma of the mediastinum with immature T cells and association with myasthenia gravis. Am J Surg Pathol 34: 742-745, 2010

69. Kim WY, Kim H, Jeon YK and Kim CW: Follicular dendritic cell sarcoma with immature T-cell proliferation. Hum Pathol 41: $129-133,2010$

70. Suhail Z, Musani MA, Afaq S, Zafar A and Ahmed Ashrafi SK: Follicular dendritic cell sarcoma of tonsil. J Coll Physicians Surg Pak 20: 55-56, 2010

71. Suchitha S, Sheeladevi CS, Sunila R and Manjunath GV: Extra nodal follicular dendritic cell tumor. Indian J Pathol Microbiol 53: 175-177, 2010.

72. Amiri-Kordestani L, Priebat D and Chia SH: Follicular dendritic cell sarcoma of the neck: case report and review of current diagnostic and management strategies. Ear Nose Throat J 89: E14-E17, 2010.

73. Eun YG, Kim SW and Kwon KH: Follicular dendritic cell sarcoma of the tonsil. Yonsei Med J 51: 602-604, 2010.

74. Duan GJ, Wu F, Zhu J, et al: Extranodal follicular dendritic cell sarcoma of the pharyngeal region: a potential diagnostic pitfall, with literature review. Am J Clin Pathol 133: 49-58, 2010.

75. Li L, Shi YH, Guo ZJ, et al: Clinicopathological features and prognosis assessment of extranodal follicular dendritic cell sarcoma. World J Gastroenterol 16: 2504-2519, 2010.

76. Martins PN, Reddy S, Martins AB and Facciuto M: Follicular dendritic cell sarcoma of the liver: unusual presentation of a rare tumor and literature review. Hepatobiliary Pancreat Dis Int 10: 443-445, 2011.

77. Silver AL, Faquin WC and Deschler DG: Follicular dendritic cell sarcoma presenting in the submandibular region in an 11 year-old. International Journal of Pediatric Otorhinolaryngology Extra 6: 104-106, 2011

78. Fareed MM, Memon MA, Rashid A, et al: Follicular dendritic cell sarcoma of the neck with pulmonary metastases. J Coll Physicians Surg Pak 21: 561-563, 2011. 
79. Li Z, Jin K, Yu X, et al: Extranodal follicular dendritic cell sarcoma in mesentery: A case report. Oncol Lett 2: 649-652, 2011.

80. Pyo JS, Kang G, Do SI, et al: Extranodal follicular dendritic cell sarcoma with rapid growth in parapharynx: a case report. Korean J Pathol 46: 306-310, 2012.

81. Mondal SK, Bera H, Bhattacharya B and Dewan K: Follicular dendritic cell sarcoma of the tonsil. Natl J Maxillofac Surg 3: 62-64, 2012.

82. Karabulut B, Orhan KS, Guldiken Y and Dogan O: Follicular dendritic cell sarcoma of the nasopharynx. Int J Oral Maxillofac Surg 41: 218-220, 2012.

83. Malik A, Veniyoor A, Fanthome B and Dutta V: Follicular dendritic cell sarcoma: a diagnostic challenge! J Cancer Res Ther 8: 306-307, 2012.

84. Hu T, Wang X, Yu C, et al: Follicular dendritic cell sarcoma of the pharyngeal region. Oncol Lett 5: 1467-1476, 2013.

85. Saygin C, Uzunaslan D, Ozguroglu M, Senocak M and Tuzuner N: Dendritic cell sarcoma: a pooled analysis including 462 cases with presentation of our case series. Crit Rev Oncol Hematol 88: 253-271, 2013.

86. Choe JY, Go H, Jeon YK, et al: Inflammatory pseudotumor-like follicular dendritic cell sarcoma of the spleen: a report of six cases with increased IgG4-positive plasma cells. Pathol Int 63 : $245-251,2013$
87. Yu H, Gibson JA, Pinkus GS and Hornick JL: Podoplanin (D2-40) is a novel marker for follicular dendritic cell tumors. Am J Clin Pathol 128: 776-782, 2007.

88. Chan JK, Tsang WY, Ng CS, et al: Follicular dendritic cell tumors of the oral cavity. Am J Surg Pathol 18: 148-157, 1994

89. Wook YK, Haeryoung K, Yoon KJ, et al: Follicular dendritic cell sarcoma with immature T-cell proliferation. Human Pathology 41: 129-133, 2010.

90. Marc H, Philipp S, Manfred D, et al: A Follicular Dendritic Cell Sarcoma of the Mediastinum With Immature T Cells and Association With Myasthenia Gravis. Am J Surg Pathol 34 742-745, 2010.

91. Hsu C, Vega F, Grimes LM and Hunt KK: Follicular dendritic cell sarcoma and associated myasthenia gravis: true, true, related? J Clin Oncol 29: e369-e371, 2011.

92. Jaffee ES, Harris NL, Stein H and Vardiman JW, editors: World Health Organization classification of tumors. Pathology and genetics of tumors of hematopoietic and lymphoid tissues. Lyon: IARC Press 2001.

93. Chan JKC, Pileri SA, Delsol G, et al: Follicular dendritic cell sarcoma. In: WHO Classification of Tumours of Haematopoietic and Lymphoid Tissues. Swerdlow SH, Campo E, Harris NL, Jaffe ES, Pileri SA, Stein H, Thiele J and Vardiman JW (eds). 4th edition. IARC Press, Lyon, pp363-364, 2008. 